doing for the War. Nearly five hundred of them have been approved tentatively, and subject to inspection will take allotted parts in war-training programmes. Obviously the normal course of scientific and technical education is being suspended, but on the other hand an immense stimulus is being given to forms of training that are destined to remain after hostilities have ceased.

\section{Russian Interest in Mathematical Statistics}

A CABLE from Prof. Alexander Schneiderman informs us that the centenary of Rothamsted Experimental Station was celebrated on July 21 at a meeting held in the Moscow Scientists' Club. Prof. Dmitri Prianishnikov, the 'father of Russian agricultural chemistry' and one of Timiriazev's closest collaborators, presented a historical review in which he indicated the part Rothamsted had performed in laying the foundations of chemistry applied to agriculture. Experimental fields in emulation of the classical trials of Lawes and Gilbert had been laid. out in several countries; the Russian Institute for Research in Fertilizers has its own experimental field and conducts experiments at three hundred places in various soil zones of the Union.

Particular attention was given to Rothamsted's development of statistical methods, including the analysis of variance, in the design and interpretation of field experiments-a subject which hitherto has been noticed (by Russians) only by V. Romanovsky. Prof. Vassily Nemchinov read a paper on the significance of the work of the Rothamsted Statistical Department, founded in 1919 at the instigation of Sir John Russell. Prof. Nemchinov said that the idea of organizing a statistical department was characteristic of Rothamsted, as it involved collaboration between field workers, mathematicians, and pure biologists. A new branch of statistical theory had been developed, and had been very fruitful in estimating the reliability of results of both field and laboratory work.

\section{Beit Memorial Fellowships for Medical Research}

IN their annual report the trustees of the Beit Memorial Fellowships for Medical Research note the election this year again, as in 1942, of three past fellows to the fellowship of the Royal Society, namely, I. de Burgh Daly (fellow 1920-23); W. G. Penfield (1921); and S. Zuckerman (1934-37). Out of the twenty-five present fellows there are now sixteen seconded for whole-time war work. The following elections were made, with permission for each fellow to be seconded at any time for war duties: 4th Yeur Fellowships ( $£ 500$ a year): Dr. J. J. D. King, to continue his studies of dental caries and parodontal disease, at the Nutritional Laboratory of the Medical Research Council; P. C. Williams, to continue his studies of natural and synthetic œstrogens, at the Courtauld Institute of Biochemistry, Middlesex Hospital; Junior Fellowships ( $\$ 400$ a year): Margery E. M. Cutting, to study the physiological metabolism of organs in infancy, at the Department of Medicine, University of Cambridge ; Dr. A. Kleczkowski, to study serological reactions in reference to size and shape of antigen and antibody particles, at Rothamsted Experimental Station, Hertfordshire; Dr. G. J. Popjak, for an experimental study of fatty and degenerative changes in the kidney, at St. Thomas's Hospital Medical School; Dr. Ethel G. Teece, to study the chemical structure of
Gram-positive and negative micro-organisms and to develop antibacterial agents, at the Department of Chemistry, University of Birmingham.

\section{Future of Analytical Chemistry}

THe Council of the Society of Public Analysts and Other Analytical Chemists has had under consideration the desirability of the formation, within the Society, of groups or sections dealing with special subjects or branches of analytical chemistry. Many members of the Society have been concerned with the implications arising from the recent rapid development of analytical chemistry and the probable continuation of such development in the post-war period, and the need of some measure of federation and co-ordination of specialized branches of analytical chemistry was apparent. Since one of the objects for which the Society was established, as set forth in its memorandum of association, is "to encourage, assist and extend the knowledge and study of analytical chemistry", the Council believes that this purpose can be best achieved by the institution of groups within the framework of the constitution of the Society. Negotiations are already in progress with the Microchemical Club with a view to that body becoming a Microchemical Group of the Society, but the formation of other Groups also, as may be deemed desirable, within the Society will be encouraged, and proposals to this end will be submitted to a special meeting of the Society in the autumn.

\section{National Institute of Social and Economic Research}

THE annual report for 1942 of the National Institute of Social and Economic Research refers to the removal of the Institute to 2 Dean Trench Street, Westminster, where the new premises have permitted a thorough re-organization of the library. This has been re-classified and re-catalogued, and an accessions programme worked out to fill up the more serious gaps in books, periodicals and official publications. The Institute is prepared to make it available for reference to research workers in Government service who may wish to supplement the resources of their departmental libraries. Research work during the year was almost entirely a continuation or extension of programmes either under way or planned, but the first issue of the Register of Research in the Social Sciences, the new version of the summary of research in progress and in plan, was completed in December and has been circulated confidentially. The Saving and Spending Survey begun in 1940 was concluded in October, and the inquiry into National Health Insurance undertaken by Prof. H. Levy was sent to the press early this year. Dr. Baykov's study on the development of the Soviet economic system, which has taken the form of a thoroughly documented essay on the experience of planning in the U.S.S.R., was concluded by the end of the year. Dr. Singer completed in November a short descriptive study of standardized accountancy in Germany and Prof. Findlay Shirras brought to a close in the autumn the "Federal Finance Enquiry". Mr. A. Shentield completed a report on "The Impact of War on Coventry : a Study in Industrial Dislocation", covering the war period up to the end of 1941 .

Three inquiries, on national expenditure, output, and income, 1920-38, on the measurement of national income of selected Colonial territories, and on the burden of local taxation, which had already begun, were continued throughout the year and are being 
carried on in 1943. The second of these was originally concerned with Northern Rhodesia and Jamaica, but has now been extended to Nyasaland in view of the valuable data on that Colony which became available during the year. With regard to the third, a paper on the expenditure of county boroughs in England is now in the press and the full inquiry will be published under the title "Wealth and Poverty in Local Government", as there are insufficient data to permit a calculation of the local tax burden comparable with that made for the national tax survey in "The Burden of British Taxation". Of the inquiries upon which work only started in 1942 , that into profit margins is the most significant. Other plans which came into operation during the year were Dr. R. R. Kuczynski's study of post-war population problems, and studies in aspects of commercial policy, directed by Dr. P. Barrett Whale. Two continuous projects were initiated in 1942 : the observational study of the effects of the War on the credit policy and credit mechanisms of the City of London and the "Weekly Diary: Summary of Economic and Social Changes". It is intended to continue the former for the duration of the War, and a full-length descriptive and analytical summary is expected to result.

\section{Vital Statistics of Canada}

ACCORDING to the twentieth annual report on vital statistics for 1940 and the preliminary annual report for 1941 , both recently issued by the Canadian Bureau of Statistics, the population of the Dominion has increased in the last twenty years from 8,776,000 in 1921 to $11,443,000$ in 1941. The largest populations were found in Quebec $(3,329,000)$ and Ontario $(3,765,000)$. Although the birth-rate for $1941(22 \cdot 3$ per 1,000 population) showed a slight increase, the rate has fallen from an average of $24 \cdot 1$ in the quinquennium $1926-30$ to $21 \cdot 5$ in 1940 . The rate was highest in New Brunswick $(25 \cdot 9)$ and lowest in British Columbia $(17 \cdot 4)$. The stillbirth-rate in 1941 was $2 \cdot 6$ per cent of all births. As regards infant mortality the provisional figure for 1941 was 60 per 1,000 live births and the rate of 56 for 1940 was the lowest recorded. The maternal mortality-rate for 1940 was $4 \cdot 0$ per 1,000 births and that for 1941 was $3 \cdot 5$. The marriage-rate showed a progressive increase from $7 \cdot 3$ per 1,000 population in the period $1926-30$ to 10.8 in 1940 and 10.7 in 1941. The general deathrate was $9 \cdot 6$ per 1,000 , the lowest rate being found in Saskatchewan and in Alberta.

\section{Sources of Engineering Information}

THE fifth number of the A S L I B War-time Guides to British Sources of Specialised Information (March 1943) deals with engineering other than electrical. These are listed under Government departments; professional, research and trade organizations; and educational organizations and technical educational organizations. The list of Government departments is not comprehensive, but is confined to sources of information still usually accessible. All references to industrial firms have been omitted. Electrical engineering and telecom. munications are covered by Guide No. 3. An additional section lists a number of organizations dealing with fuel, raw materials, transport, etc., which while not directly related to engineering are concerned with materials and aspects of work of immediate interest to engineers. The section devoted to periodicals lists separately those printing abstracts or lists of references; periodicals issued by professional and industrial organizations; other trade and technical periodicals; selected periodicals relating to auxiliary interests; engineering annuals; and annuals dealing with auxiliary interests.

\section{Recent Earthquakes}

The U.S. Coast and Geodetic Survey, in co-operation with Science Service and the Jesuit Seismological Association, has determined the epicentres of two recent earthquakes. The first of these was on June 8 at about $20 \mathrm{~h} \cdot 42 \cdot 2 \mathrm{~m}$. U.T. and occurred near latitude $19^{\circ} \mathrm{N}$., longitude $116^{\circ} \mathrm{E}$. This is in the South China Sea, west of Luzon in the Philippine Islands. The second was on June 9 at about $3 \mathrm{~h} .6 \cdot 7 \mathrm{~m}$. U.r. and had its epicentre near latitude $9^{\circ} \mathrm{N}$., longitude $120^{\circ} \mathrm{E}$., which is in the Sulu Sea north-east of Borneo. On the morning of Friday, July 16, a strong earthquake was felt throughout the Island of Jamaica. The epicentre was some ninety miles from Kingston in the Balaclava district, where some damage was done to property though there are no reports of any loss of life.

\section{Announcements}

THE Association of Scientific Workers (West Midland Area) has arranged an open conference on "Science under Fascism and Democracy", to be held at the Town Hall, Birmingham, on August 22 at 3 p.m. The Lord Mayor of Birmingham (Councillor W. S. Lewis) will open the conference, and the chair will be taken by Prof. M. L. E. Oliphant. Among the speakers who will deal with the sharp contrast in the approach to science and its applications, and also the treatment of scientific workers, in Democratic and Fascist countries, are Prof. J. B. S. Haldane (Great Britain), Dr. J. H. Hildebrand (United States), P. H. Yap (China), M. Fournier (France), Dr. A. van Anrooy (Holland), Dr. B. Schober (Czechoslovakia), Dr. A. Fischer (Austria), and Dr. J. G. Siebert (Germany). In the evening following the conference, films will be shown depicting scientific activities in many countries.

The fifth supplement to the "British Pharmaccutical Codex" contains new monographs describing the insecticides derris and lonchocarpus, and new regulations which are introduced because of the shortage of rubber and quinine. Where the "Codex" insists on rubber, the supplement allows other materials to be used, and where the "Codex" includes quinine the supplement omits it except in the cases where it is considered essential. This supplement also includes a cumulative index to all the five supplements which have been issued.

The New York Academy of Medicine, in co-opera. tion with the State Department of Health, the City Department of Health and six of the leading voluntary organizations of maternal welfare and child health, recently celebrated the hundredth anniversary of the publication by Oliver Wendell Holmes of the paper entitled "The Contagiousness of Puerperal Fever".

Erratum. In the letter entitled "Production of Ion Clusters by X-Rays" (Nature, June 19), sixth line from bottom of first column, p. 698, for " $B_{Z}=11 \cdot 2$ ev." read " $B_{Z}=11 \cdot 2 Z$ ev.". 